\title{
Hands on management of muscle pain and injuries
}

\author{
Natalie Schellack,* Palesa Masuku, Kgarebe Mogale, Nelly Mokwele, Phumzile Skosana
}

School of Pharmacy, Faculty of Health Sciences, Sefako Makgatho Health Sciences University

*Corresponding author, email: natalie.schellack@smu.ac.za

\begin{abstract}
Sport injuries and muscle pain can occur as a result of engagement in exercise and or organised sporting activities. These injuries affect all age groups and gender. The most common types of sporting activities known to cause these injuries include jogging, cycling, volley ball, swimming and heavy weight lifting. Lack of warming-up before participating in sporting activity, overtraining and or excessive exposure to these physical activities may increase the risk of injury. These factors are categorised as extrinsic factors. Intrinsic factors that may lead to sport injuries or may precipitate these injuries are age, previous injuries and level of flexibility. The most common type of injuries seen are sprains and strains. These injuries are accompanied by pain, swelling and redness of the injured area. Non-pharmacological and pharmacological management is available for the effective management of these injuries. Pain may vary from mild to severe depending on the severity of injury. These varying types of pain can be managed optimally using non-narcotics, such as paracetamol, and non-steroidal anti-inflammatory (NSAIDs), like ibuprofen. Topical therapies of NSAIDs such as ibuprofen, diclofenac and flurbiprofen are often highly effective for managing sports-related muscle sprains and strains.
\end{abstract}

When pain is categorised as moderate to severe, narcotics may be prescribed and administered.

Keywords: sport injuries, sprains, strains, PRICE, TENS, topical management, NSAIDs

\section{Key Summary Points}

- Sports injuries are injuries that occur during exercise or sporting activities.

- These injuries can occur as a result of intrinsic or extrinsic factors.

- These injuries can be classified as acute or chronic and further classified as microtrauma or macrotrauma.

- The most common types of sport injuries include sprain, strain, groin pull, and knee injury.

- Optimal management includes non-pharmacological management (PRICE, TEN) and pharmacological management (analgesic, narcotics, non-narcotics).

- Topical therapies are often highly effective for managing sports-related muscle sprains and strains.

\section{Introduction}

Participation in exercise and sporting activities offers many benefits and should be encouraged. It assists with weight management, maintaining overall health, improving a person's wellbeing and it provides psychological benefits. However, these activities are associated with risks and complications, such as sport injuries (Figure 1).

The most common types of sport activities associated with sporting injuries are ${ }^{2}$ :

\section{- Running or jogging}

- Contact sports - rugby, soccer, hockey and boxing

- Racket sports - tennis, badminton

- Volleyball

- Basketball

- Heavy weight lifting

- Cycling

- Golfing

- Swimming

Topical therapies are often highly effective for managing sportsrelated muscle sprains and strains.

The skin is essential for maintaining body homeostasis and for preventing uptake of harmful substances in the environment. ${ }^{3}$ This topical route of administration is used for a number of conditions and a number of drugs. ${ }^{4}$

Topical administrations often have similar efficacy to oral administration but potentially have a more favourable tolerability profile, since they have fewer systemic side effects and drug interactions. ${ }^{4}$ Transdermal drug administration also bypasses first pass metabolism of drugs by the liver, allowing longer drug administration periods and the drugs can be better controlled and tolerated by the patient. This in turn leads to reduced side effects, more stable dosage levels and increased patient compliance. 
Oral administration of muscle relaxants is associated in particular with a high rate of sedation and gastrointestinal disorders. Therefore, application of these therapies is limited by the spectrum of undesirable side effects. ${ }^{5}$

When the intended site of action for the topically applied drug is the skin itself, the route of administration is considered to be topical (local). When the intended site of action is systemic, the route of administration is considered to be transdermal. ${ }^{6}$ However, for any topically applied drug to act (locally or systemically), it must penetrate the layers of the skin, the stratum corneum ${ }^{5}$ and be able to permeate to the target areas in quantities sufficient to exert a therapeutic effect. ${ }^{7}$

Movement of the drug through the skin is via the passive diffusion process, relying on down concentration gradients (following Fick's Law) and partitioning into tissues and solutes. ${ }^{8}$ Active transport processes can occur, but the mechanisms have not been identified. Some of the drugs travel from the surface of the skin via the hair follicles or sweat ducts to reach the lower layers of the skin'; furthermore, the sweat ducts and hair follicles act as diffusion hunts for topical preparations. ${ }^{9}$

The stratum corneum is the outermost, horny layer of skin that limits penetration of foreign substances to protect the structures beneath. It can be very difficult to penetrate this layer passively hence it is the rate-limiting step for epidermal drug transport. ${ }^{8}$ At the dermal level, the drug may enter the local blood vessels for distribution to deeper tissues and from the dermal microcirculation into the systemic circulation. ${ }^{8}$ Therefore the success of topically applied drugs is highly dependent on the pharmacological characteristics and pharmacodynamic profile of each drug. ${ }^{4}$

Data on the penetration of water and lowmolecular-weight nonelectrolytes have given evidence that permeability through the epidermis is directly proportional to concentration at the site of application. ${ }^{9}$ The stratum corneum is slightly permeable to both water-soluble and lipid-soluble substances. ${ }^{10}$

The effect of hydration on skin permeability is also evident in clinical practice as occlusive dressings that increase the water content of stratum corneum generally dramatically potentiate the effect of drugs locally applied to skin. ${ }^{8}$

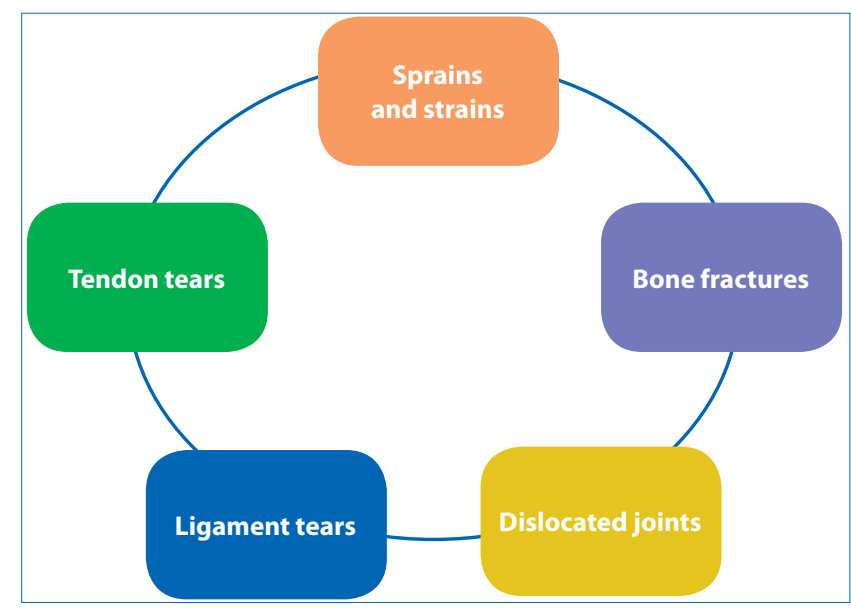

Figure 1: The most common types of sports injuries

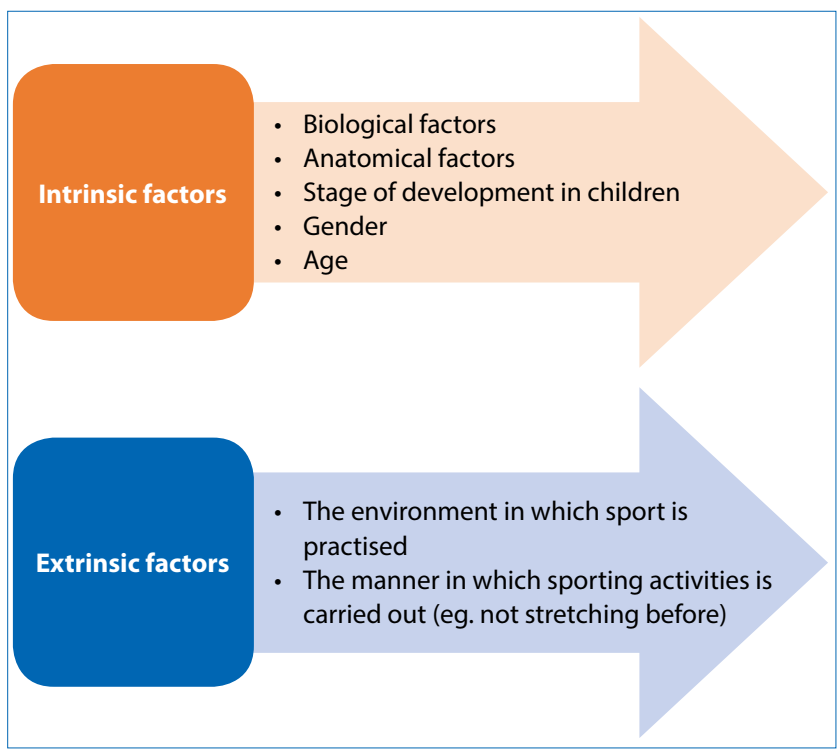

Figure 2: Risk factors of sports injuries

\section{Causes of sport injuries}

The term sports injuries is used to describe any injury that occurs during exercise and sporting activities. ${ }^{1}$ Sporting injuries can result from:

- Accidents while playing sport

- Insufficient warming-up

- Poor training processes

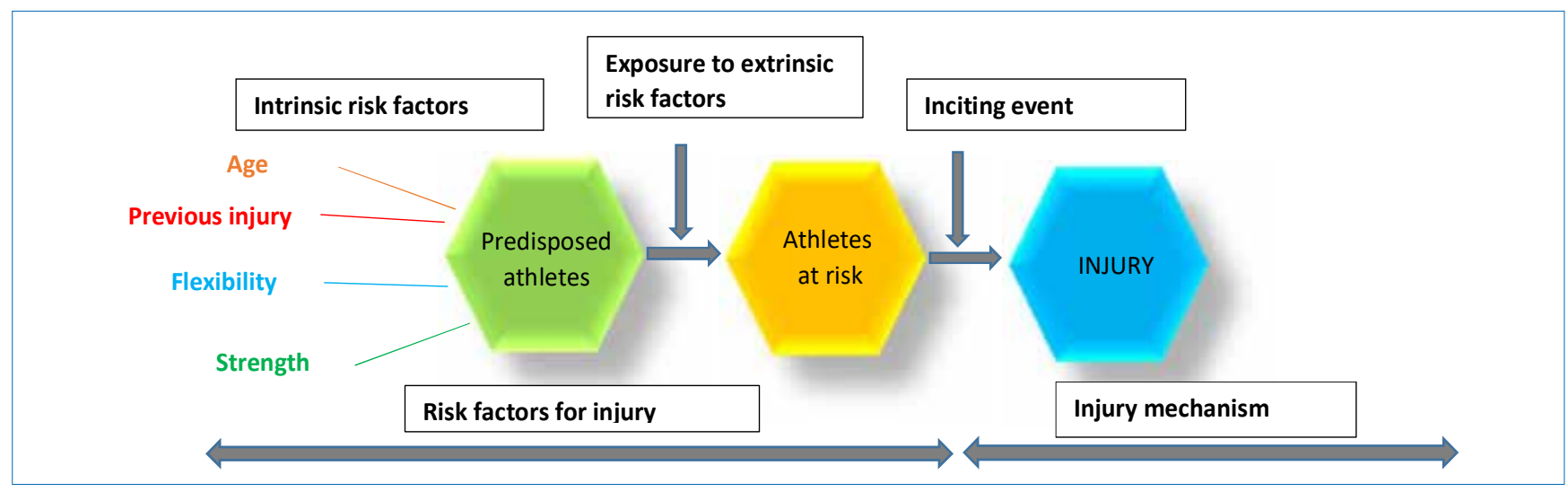

Figure 3: Risk factors for sport injuries ${ }^{12,13}$ 
- Lack of equipment or proper equipment (e.g., inappropriate boxing gloves)

\section{Risk of sports injuries}

There are many different types of sports injuries that can occur. The most common include sprains, tears, dislocations and fractures (Figure 1). ${ }^{11}$

Sports injuries can occur due to many different factors. These factors include intrinsic and extrinsic factors (Figure 2 and 3) ${ }^{10}$ Intrinsic factors refer to factors that makes a person more vulnerable to getting injured. Extrinsic factors include environmental factors that affect how a sporting activity is done. ${ }^{10,11}$

A person carries an intrinsic predisposition to getting injured. After the person is exposed to an extrinsic risk (e.g., not wearing the correct shoes), an injury will occur. ${ }^{10}$

\section{Classification of sports injuries}

Sports injuries are generally classified as acute or traumatic and chronic/overuse regardless of the affected structure. ${ }^{12}$

Acute or traumatic injuries include sprains, cuts, fractures and concussions. These injuries have a sudden onset and heal relatively quickly. ${ }^{12}$

Chronic injuries are a result of overusing one area of the body while playing sport. It takes a long period of time to develop a chronic injury and healing takes much longer than an acute injury. ${ }^{12}$

The signs and symptoms of acute and chronic injuries are listed in Table 1 below ${ }^{12}$ :

Table 1: Signs and symptoms of acute and chronic sport injuries ${ }^{4}$

\begin{tabular}{ll}
\hline Acute Injury & Chronic Injury \\
\hline Sudden onset of pain & Swelling at site of injury \\
\hline $\begin{array}{l}\text { Severe pain } \\
\text { Bleeding if there is a cut or }\end{array}$ & Dull uncomfortable pain at rest \\
grazing & Pain when performing activity \\
\hline Visible discoloration or bruising & $\begin{array}{l}\text { Inability to move joint through } \\
\text { its full range of movement }\end{array}$ \\
\hline $\begin{array}{l}\text { Swelling } \\
\text { Tenderness }\end{array}$ & \\
\hline $\begin{array}{l}\text { Inability to put weight onto a } \\
\text { lower limb }\end{array}$ & \\
\hline $\begin{array}{l}\text { Weakness of the limb or joint } \\
\text { Inability to move joint through } \\
\text { its full range of movement }\end{array}$ \\
\hline
\end{tabular}

Sport injuries may also be classified as microtraumas and macrotraumas ${ }^{14}$ :

- Microtraumas result from constant injury to a certain part of the body or overuse of a certain muscle, joint, tissue, etc. Further to this they include tears in fibre and connective tissues as well as strains and overstretched tendons.
- Macrotraumas occur with a single traumatic event and includes cuts, bruises, sprains and fractures followed by swelling and loss of function. ${ }^{14}$

\section{Types of sports injuries}

Sprains

Sprains are caused when there is a stretch or tear of the ligament. Sprains generally happen when there is a hard knock to the body causing trauma to the ligament. ${ }^{15}$

There are different degrees of sprains ranking from a partial tear to a severe tear and this is classified in Table 2.

Table 2: Classification of sprains

\begin{tabular}{ll}
\hline Degree of sprain & \\
\hline Degree 1 & $\begin{array}{l}\text { Partial/slight tear } \\
\text { Joint is still stable } \\
\text { Little pain and swelling }\end{array}$ \\
Degree 2 & $\begin{array}{l}\text { Moderate tear } \\
\text { Joint is moderately unstable } \\
\text { Moderate to severe pain or swelling }\end{array}$ \\
Degree 3 & $\begin{array}{l}\text { Complete rupture } \\
\text { Joint is completely unstable } \\
\text { Severe pain and swelling } \\
\text { Generally other tissues are also affected }\end{array}$ \\
\hline
\end{tabular}

Strains

A strain is most commonly known as a 'muscle pull' or 'torn tendon'. A strain occurs when there is damage to a muscle fibre or to a tendon. ${ }^{15}$

Just like sprains, there are also different degrees of muscle strains ranging from a first degree or mild strain to a third degree or most severe strain refer to Table 3 .

Table 3: Classification of strains

\begin{tabular}{ll}
\hline Degree of strain & \\
\hline Degree 1 & $\begin{array}{l}\text { Partial/ slight tear } \\
\text { Full range of motion accompanied by pain } \\
\text { Tenderness at sight of tear }\end{array}$ \\
Degree 2 & $\begin{array}{l}\text { Moderate tear to the tissue or tendon } \\
\text { Limited movement } \\
\text { Moderate to severe pain } \\
\text { Swelling and possibly depression at the site of } \\
\text { injury } \\
\text { Complete tear } \\
\text { No movement } \\
\text { Exceptionally painful initially, however, it can be } \\
\text { painless after the initial injury }\end{array}$ \\
\hline
\end{tabular}

Knee injury

Knee injuries are fairly common especially in weight bearing sports or weight training exercises. Knee injuries also range from mild injuries to severe injuries. However, a slight injury to the knee may render severe pain and limit the range of motion. The three most common knee problems encountered are: runners knee, iliotibial band syndrome and tendonitis (Figure 4). More severe injuries to the knee include damage to the bone, cartilage or ligaments. ${ }^{12}$ 


\section{Runners knee}

- Pain or tenderness is experianced at the front or side of the knee close to the knee cap

lliotibial band syndrome

- Pain is experienced on the outer part of the knee

\section{Tendonitis}

- Degeneration of the tendon

Figure 4: Types of knee injuries

Groin pull

This occurs due to a continuous pushing off in a side-to-side motion, which may lead to strain of the muscles of the inner thigh or groin. This can occur in individuals who participate in sports such as, hockey, soccer, football, and baseball. ${ }^{16}$

\section{Shin Splints}

This occurs on the lower legs as a radiating pain down the lower legs. This occurs mostly as a result of running particularly when starting a more strenuous training program such as long runs on paved roads. ${ }^{16}$

\section{Tennis elbow}

This occurs when there is a repetitive use of the elbow, for example in sports like golf and tennis which involve lots of swings. These swings can lead to irritation or small tears in the tendon of the elbow. This is also known as epicondylitis. It is very common in tennis and golf players and occurs more commonly in adults 30-60 years old. ${ }^{16}$

\section{Components to effectively prevent and manage injury}

Injuries that occur during sporting activities can be prevented and managed effectively as illustrated by Figure 5 . It is important not to exclude rehabilitation of these injuries to help facilitate recovery. Rehabilitation should take place under the supervision of qualified professionals (e.g., physiotherapists) before engaging in any sport activity, to prevent risk of worsening of the original injury. ${ }^{17}$

\section{Prevention of sport injuries}

To prevent injuries, all sport activities should begin with a gentle warm-up to increase blood flow to the muscles and to increase

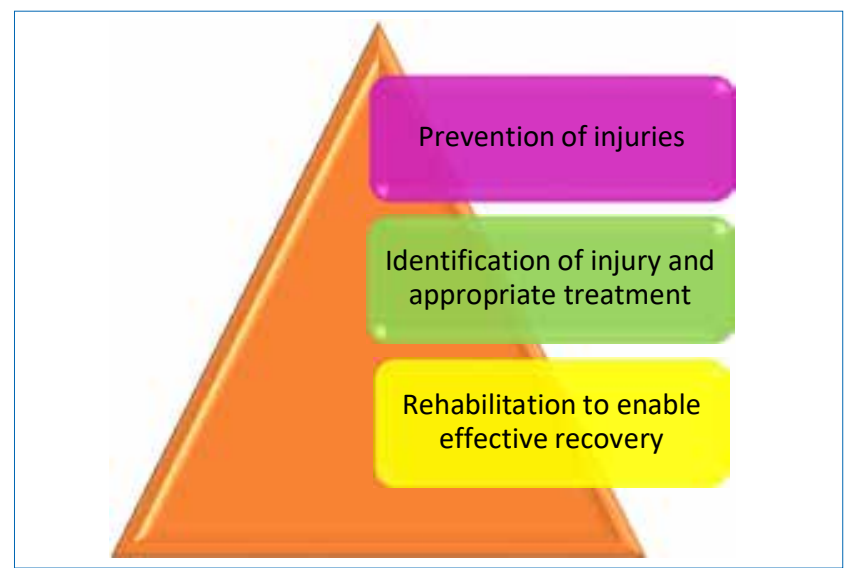

Figure 5: Components to effectively prevent and manage injury flexibility. Table 4 provides possible strategies or options on how to prevent these sport injuries. ${ }^{16,17}$

Table 4: Tips on how to prevent sport injuries ${ }^{9}$

- Warm up and cool down before and after sport

- Remain hydrated before, during and after sport

- Wear footwear with the appropriate support and grip

- Tape or strap vulnerable or previously injured joints and limbs

- Maintain a good level of overall fitness and muscle strength

- Don't exert yourself too far beyond your level of fitness, rest or stop when fatigued

- Slowly increase the intensity of your training routine

- Always practice the correct technique and get advice from professional trainers

- Permit satisfactory recovery time between sessions

\section{Management of sport injuries}

Typically most of the common sports injuries are mild to moderate and can be managed effectively at home, depending on the severity of the injuries, through techniques such as PRICE therapy method (Protect from injury, Restrict activity, Ice the injured area, Compression and Elevation) which is discussed under non-pharmacological management in this article (Figure 6). It is important to educate patients that injuries may take months to heal even when managed effectively. Surgery may be required depending on severity of the injuries for example a tear in muscles or ligaments. ${ }^{16}$

\section{Non-pharmacological management}

The standard golden treatment of any sports injury, especially sprains and strains, is PRICE. The PRICE principle (Figure 6) helps by limiting the amount of swelling at the site of injury and preventing more injury to that specific tissue. $15,16,18$ Restricting activity for up to 72 hours will help with the healing process. Whist activity is being restricted, small muscle movements should be initiated. Icing the area helps reduce swelling and should be done for 15-20 minutes every 60-90 minutes. Compression with an elastic bandage should be considered. Raising/elevating the affected limb should be encouraged in order to reduce swelling at the site of injury. ${ }^{15,16,18}$ Different types of sports injury generally have a different treatment approach. These treatment options are discussed below in Table 5 .

Sports injuries are commonly accompanied by muscle pain.

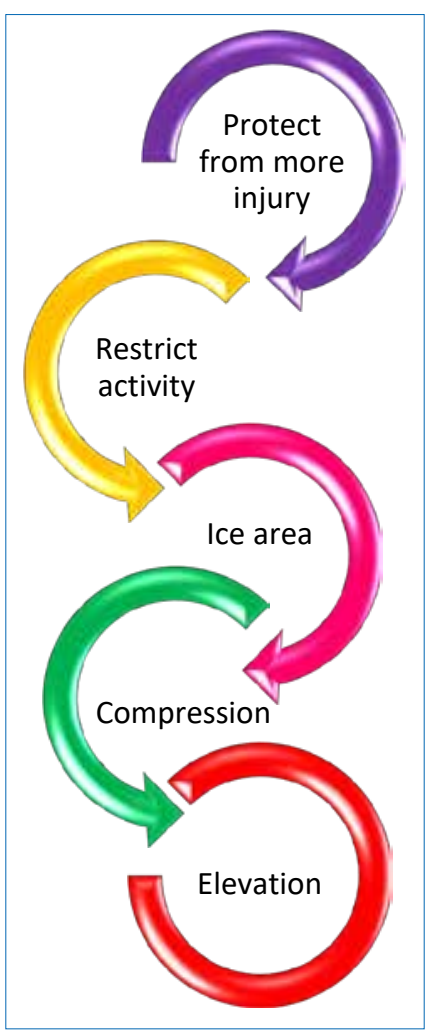

Figure 6: Management of sports injuries using the PRICE principle 
Figure 7 below demonstrates the different methods used to relieve sports injuries without using any pharmacological agents.

Treatment modalities include the following:

\section{Transcutaneous electrical stimulation (TENS)}

TENS is used to modulate pain. It is a non-invasive technique. ${ }^{19}$ TENS works by delivering electrical current through the skin in order to decrease central excitability. Thus, the nociceptive neurons in the spinal cord are inhibited, decreasing acute and chronic pain. ${ }^{20}$

\section{Acupuncture}

Acupuncture is a Chinese based treatment modality. It works by targeting specific points of the body to improve health and reduce pain. Several mechanisms have been hypothesised. Acupuncture is usually done when conventional methods of chronic pain management have failed ${ }^{21}$

\section{Thermal modalities}

Thermal modalities are another method of managing muscle pain in sports injuries. These methods use heat. ${ }^{22}$ Temperatures used are greater than normal body temperature. Treatment modalities are usually classified as superficial or deep:

- Superficial thermotherapy - depth of heat used is usually $1 \mathrm{~cm}$ deep. Modalities used include; dry heating pad, moist heating pad and paraffin baths.

- Deep thermotherapy - depth of heat used is usually between 3-5 cm deep. Device used to administer the heat includes therapeutic ultrasound

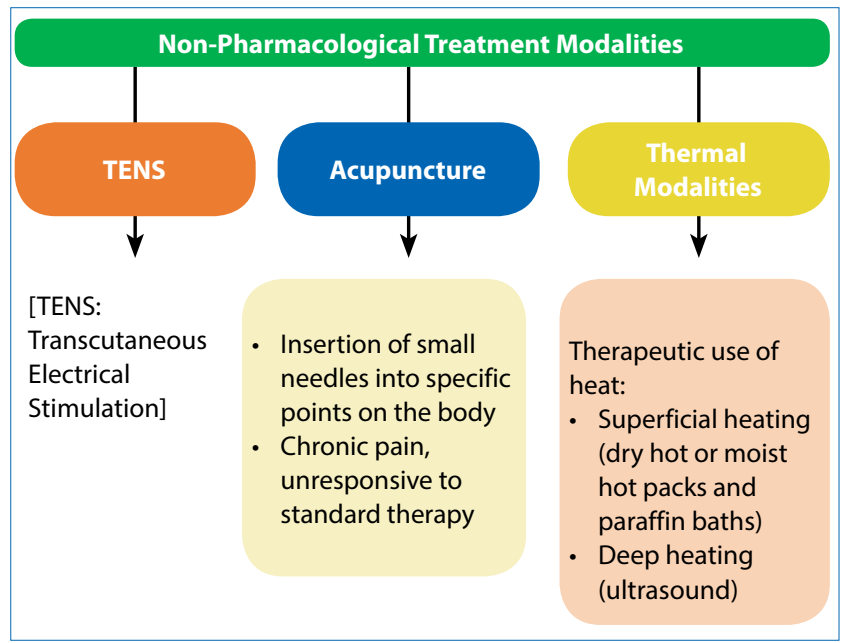

Figure 7: Treatment of muscle pain in sports injuries

\section{Advice to patients}

Non-pharmacological management and self-applied management techniques may help resolve injury, but may not be efficient enough to heal the injury. Therefore it is important to ask patients to come back should the injury not heal. ${ }^{8}$ Patients should be advised to return to the health care professional, if they experience any of the signs listed below:
Table 5: Sport injuries and how to manage them

\begin{tabular}{|c|c|}
\hline $\begin{array}{l}\text { Types of sport } \\
\text { injuries }\end{array}$ & What to do \\
\hline Sprains & $\begin{array}{l}\text { When a patient has a sprain, it is vital } \\
\text { to exercise the body part affected. This is to } \\
\text { prevent any loss of flexibility and strength in } \\
\text { that area. In determining the kind of exercise } \\
\text { required, a consultation with a doctor or a } \\
\text { physiotherapist is advised so as not to hurt the } \\
\text { area any further while exercising. }\end{array}$ \\
\hline Strains & $\begin{array}{l}\text { Strain injuries take time to heal due to } \\
\text { the continuous stress exerted on injured } \\
\text { tissue while walking. Healing can take six } \\
\text { months to a year. Apply PRICE principle } \\
\text { as discussed above. Use over-the-counter } \\
\text { pain medication like aspirin, ibuprofen or } \\
\text { paracetamol particularly for children younger } \\
\text { than } 18 .\end{array}$ \\
\hline $\begin{array}{l}\text { Knee injuries } \\
\text { (runners knee, } \\
\text { iliotibial bond } \\
\text { syndrome, } \\
\text { tendonitis) }\end{array}$ & $\begin{array}{l}\text { It is important to be patient. These types of } \\
\text { injury take up to six weeks to heal properly. It is } \\
\text { helpful to continue low-impact exercise during } \\
\text { this time. Working out the quadriceps may also } \\
\text { relieve pain. }\end{array}$ \\
\hline Groin pull & $\begin{array}{l}\text { Best way to manage this injury is by applying } \\
\text { compression, ice, and rest. But returning to } \\
\text { full activity quickly before it has fully healed } \\
\text { may aggravate the groin pull or turn it into a } \\
\text { long-term injury. }\end{array}$ \\
\hline Shin splints & $\begin{array}{l}\text { Rest, applying ice, and over-the-counter pain } \\
\text { medicine (ibuprofen, diclofenac, paracetamol) } \\
\text { are the best way to treat this injury. }\end{array}$ \\
\hline $\begin{array}{l}\text { Tennis elbow } \\
\text { (Epicondylitis) }\end{array}$ & $\begin{array}{l}\text { Epicondylitis usually resolves itself if patients } \\
\text { stay off the tennis court or golf course for } \\
\text { a period of time until the pain resolves or } \\
\text { improves. Placing ice on the elbow may help } \\
\text { reduce pain and swelling. Use elbow straps } \\
\text { to protect and support the injured area and } \\
\text { to prevent further strain. Give non-steroidal } \\
\text { anti-inflammatory (ibuprofen, naproxen, or } \\
\text { aspirin) to assist with the management of pain } \\
\text { and swelling if necessary. }\end{array}$ \\
\hline
\end{tabular}

- Presence of any defects in the joint or bone - it looking or moving uncharacteristically ${ }^{16}$

- Unable to tolerate weight or inability to use the limb without serious pain or support

- Extreme swelling

- Any changes in skin colour other than mild bruising

- Not feeling any better after a few days of PRICE therapy and other self-applied management techniques.

\section{Management of muscle pain}

\section{Pharmacological management}

There are various classes of medicines that may be used in the management of sport related injuries. The most common classes include narcotic analgesics, non-narcotic analgesics and adjuvants. Optimal pain management includes using a multi-model approach to treating pain. ${ }^{15}$ This includes the use of two or more analgesics that bring about analgesia differently and that could be administered differently but still work in synergism. The multi-model approach also integrates the use of 
non-pharmacological therapy with pharmacological in order to treat the patient holistically. ${ }^{22}$

\section{Analgesics}

These agents are used precisely to relieve pain. Analgesics include narcotic and non-narcotic agents. These agents have different mechanisms of action and therefore exert different side effects which should be taken into consideration when prescribing/administering these agents to patients. ${ }^{23}$

\section{Non-narcotic analgesics}

There are several non-narcotic analgesic agents available on the market for the management of pain especially in children. ${ }^{22}$ These medicines include paracetamol and non-steroidal antiinflammatory (NSAIDs) like ibuprofen. These medicines are used to manage mild to moderate pain, but when used in combination with a narcotic analgesic can be used to manage severe pain. ${ }^{22}$

\section{Paracetamol}

Paracetamol is available over the counter for both adults and children with sport injuries. The maximum dose should not exceed $4000 \mathrm{mg}$ (4 grams) per day. When used for children, it is important to follow the recommended dosages included on the product's packaging. ${ }^{23}$ Paracetamol is the most common drug of choice due to its safety and efficacy profile. ${ }^{24}$

Paracetamol is a pro-drug which is converted to an active metabolite, cannabinoid. $N$ - arachidonolylphenolamide is formed following the de-acetylation of paracetamol in the brain and spinal cord to form its primary amine ( $p$-aminophenol). The involved enzyme is fatty acid amide hydrolase. $\mathrm{N}$-arachidonolylphenolamide acts as an agonist on the Transient Receptor Potential Cation Channel, which is a Subfamily V, Member 1 (TRPV1) receptor and an inhibitor of cellular anandamide uptake. This leads to an increase in the levels of endogenous cannabinoids, which inhibit cyclooxygenases in

Table 6: Formulations, dosages and side-effects of various pain medications

\begin{tabular}{|c|c|c|c|}
\hline Drug & Side effects & Dosage forms & Dosages \\
\hline Paracetamol & $\begin{array}{l}\text { Hypersensitivity skin reactions: } \\
\text { Skin rashes, pruritus and angioedema. } \\
\text { Neutropenia, thrombocytopenia } \\
\text { Nephrotoxicity } \\
\text { Hepatoxicity }\end{array}$ & $\begin{array}{l}\text { Tablets } \\
\text { Suppositories } \\
\text { Intravenous Solutions }\end{array}$ & $\begin{array}{l}1 \mathrm{~g} 6 \text { hourly } \\
\text { Maximum: } 4 \mathrm{~g} \text { per day }\end{array}$ \\
\hline Ibuprofen & $\begin{array}{l}\text { GIT: Gastric erosion ,peptic ulceration } \\
\text { Hypersensitivity reactions: Skin rashes, pruritus and } \\
\text { angioedema } \\
\text { Renal toxicity }\end{array}$ & $\begin{array}{l}\text { Tablets } \\
\text { Topical Patch } \\
\text { Topical Gel } \\
\text { Oral Syrup }\end{array}$ & $200-400$ mg 6-8 hourly \\
\hline Indometacin & $\begin{array}{l}\text { CNS effects: Dizziness drowsiness, mental confusion, } \\
\text { headache in less than } 10 \% \text { to patients } \\
\text { Corneal deposits }\end{array}$ & Capsules & 25-50 mg 6-8 hourly \\
\hline Ketaprofen & $\begin{array}{l}\text { GIT: Gastric erosion ,peptic ulceration } \\
\text { Hypersensitivity reactions: Skin rashes, pruritus and } \\
\text { angioedema } \\
\text { Renal toxicity }\end{array}$ & Tablets & $200 \mathrm{mg}$ daily with meals \\
\hline Diclofenac & $\begin{array}{l}\text { GIT: Gastric erosion ,peptic ulceration } \\
\text { Hypersensitivity reactions: Skin rashes, pruritus and } \\
\text { angioedema } \\
\text { Renal toxicity }\end{array}$ & $\begin{array}{l}\text { Tablets } \\
\text { Intramuscular Injection } \\
\text { Topical Gel } \\
\text { Suppositories } \\
\text { Topical Patch }\end{array}$ & $\begin{array}{l}\text { Oral: } 25-50 \text { mg } 8 \text { hourly, to maximum: } \\
150 \text { mg/day } \\
\text { Intramuscular: } 75 \mathrm{mg} 12 \text { hourly, } \\
\text { maximum of } 150 \mathrm{mg} / \text { day for } 2 \text { days only } \\
\text { Suppositories: } 100 \mathrm{mg} \text { daily at night }\end{array}$ \\
\hline Piroxicam & $\begin{array}{l}\text { GIT: Gastric erosion , peptic ulceration } \\
\text { Hypersensitivity reactions: Skin rashes, pruritus and } \\
\text { angioedema } \\
\text { Renal toxicity }\end{array}$ & $\begin{array}{l}\text { Tablets } \\
\text { Topical Gel }\end{array}$ & $\begin{array}{l}40 \mathrm{mg} \text { daily for the first two days then } \\
20 \mathrm{mg} \text { daily for up to } 14 \text { days }\end{array}$ \\
\hline Naproxen & $\begin{array}{l}\text { GIT: Gastric erosion ,peptic ulceration } \\
\text { Hypersensitivity reactions: Skin rashes, pruritus and } \\
\text { angioedema } \\
\text { Renal toxicity }\end{array}$ & Tablets & $\begin{array}{l}500 \mathrm{mg} \text { initially then } 250 \mathrm{mg} \text { 8hourly } \\
\text { Maximum: } 1 \mathrm{~g} / \text { day }\end{array}$ \\
\hline Celecoxib & $\begin{array}{l}\text { weakness, shortness breath, chest pain, visual and balance } \\
\text { impairment, slurred speech, tarry stools }\end{array}$ & $\begin{array}{l}\text { Tablets } \\
\text { Capsules }\end{array}$ & $\begin{array}{l}100-200 \mathrm{mg} 12 \text { hourly } \\
\text { Maximum: } 400 \mathrm{mg} / \text { day }\end{array}$ \\
\hline Etoricoxib & $\begin{array}{l}\text { GIT: Nausea, dyspepsia, diarrhoea, flatulence } \\
\text { Steven-Johnsons Syndrome } \\
\text { Hypersensitivity reaction: Toxic epidermal necrolysis } \\
\text { Renal toxicity }\end{array}$ & $\begin{array}{l}\text { Tablets } \\
\text { Capsules }\end{array}$ & $60-90$ mg daily \\
\hline Meloxicam & $\begin{array}{l}\text { Weakness, shortness breath, chest pain, visual and balance } \\
\text { impairment, slurred speech, tarry stools. }\end{array}$ & $\begin{array}{l}\text { Tablets } \\
\text { Capsules } \\
\text { Suppositories } \\
\text { Intramuscular }\end{array}$ & $\begin{array}{l}\text { Oral: } 7.5-15 \mathrm{mg} \text { daily } \\
\text { Rectal: } 15 \mathrm{mg} \text { daily } \\
\text { IM: } 7.5-15 \mathrm{mg} \text { daily for up to } 3 \text { days. For } \\
\text { elderly dose at } 7.5 \mathrm{mg} \text { daily maximum }\end{array}$ \\
\hline
\end{tabular}


the brain. However, the definite proof that the analgesic and antipyretic effects of paracetamol are dependent on COXinhibition is still unclear. However, it is said to achieve this effect by inhibiting both isoforms of cyclooxygenase, COX-1, COX-2, and COX-3 enzymes involved in prostaglandin (PG) synthesis. ${ }^{25}$

Paracetamol is available in a number of dosage forms. However, the choice of dosage form and the strength of the dose is entirely dependent on patient factors, like age and severity of pain. ${ }^{25}$

\section{Non-steroidal Anti-Inflammatory Drugs (NSAIDs)}

After an injury, the body responds by activating the inflammatory cascade. Inflammatory mediators are released from the damaged tissue cells. This process initially is aimed to assist with the healing process which presents with swelling, redness, pain and tenderness. However, if inflammation is not managed, it could slow the process of healing. In order to then reduce the inflammatory process and pain accompanied by this process, non-steroidal anti-inflammatory drugs (NSAIDs) such as aspirin, ibuprofen, or naproxen sodium are recommended. ${ }^{4}$ One of the side effects includes peptic ulcer and as such contra-indicated in patients with an active peptic ulcer. Aspirin should not be used in children younger than 8 years of age. Table 6 and 7 provide an overview of various analgesics available as oral and transdermal formulations.

The manner in which NSAIDs reduce inflammation is by competitively inhibiting cyclo-oxygenase (COX). COX is the enzyme needed for the conversion of arachidonic acid to prostaglandins..$^{26,27}$

The result of inhibiting COX is a reduction in prostaglandin circulation and a reduction in inflammation. NSAIDs are used as antipyretics, analgesics and anti-inflammatories. NSAIDs also exhibit similar analgesia, however their selective inhibition of either COX-1 or COX-2 or both can guide prescribing of the one agent over the other. ${ }^{27}$

Only paracetamol and aspirin are available over-the-counter (OTC). Ibuprofen may be provided for 5 days OTC, if a patient has a post-traumatic condition which presents with swelling, pain and fever. A prescription will be needed for other agents (Act 101 of 1965).

Topical formulations of NSAIDs, in addition to other select topical agents discussed in this review, are listed in Table 7. These include ibuprofen, diclofenac, piroxicam, flurbiprofen, indomethacin, ketoprofen and methyl salicylate.

The efficacy and safety of topical NSAIDs for acute musculoskeletal pain due to sports injuries were evaluated in a meta-analysis that included 61 randomised, double-blind studies with over 8000 patients. Use of topical diclofenac, ibuprofen, ketoprofen, piroxicam, or indomethacin resulted in higher rates of clinical success, defined as more than $50 \%$ pain reduction, compared to placebo. $^{28}$

The most common concentrations of these topical agents included in the assessed studies were diclofenac $1 \%$, ibuprofen $5 \%$, piroxicam $0.5 \%$, and indomethacin $1 \%$. The concentration of ketoprofen varied from $1-5 \%$ in most studies. Formulations also differed among the studies and consisted of cream, gel, patch, spray, and others. ${ }^{28}$ The most effective products were diclofenac gel, ketoprofen gel, and ibuprofen gel. ${ }^{28}$ As mentioned earlier, trends for fewer systemic adverse events with topical NSAID formulations as compared to oral NSAIDs exist, but the available data to compare topical versus oral agents is limited. ${ }^{28}$

Table 7: Drug, formulation and dosages of various transdermal analgesics

\begin{tabular}{|c|c|c|c|c|c|}
\hline Generic Name & Formulation & Dosage & Side Effects & Trade Name & Price \\
\hline \multirow{3}{*}{$\begin{array}{l}\text { Aescin/ } \\
\text { Diethylamine } \\
\text { salicylate }\end{array}$} & \multirow[t]{3}{*}{ Gel } & \multirow{3}{*}{$\begin{array}{l}\text { Apply thin layer of gel to skin of } \\
\text { affected area several times daily }\end{array}$} & \multirow{3}{*}{$\begin{array}{l}\text { Erythema desquamation, } \\
\text { urticaria }\end{array}$} & Reparil-Gel (20 g) & R 33.91 \\
\hline & & & & Reparil-Gel (40 g) & R 67.82 \\
\hline & & & & Reparil-Gel (100 g) & R 169.82 \\
\hline \multirow{2}{*}{$\begin{array}{l}\text { Benzydamine } \\
\text { hydrochoride }\end{array}$} & \multirow[t]{2}{*}{ Gel } & \multirow[t]{2}{*}{ Massage $1-2.5 \mathrm{~g}$ 3-6 times daily } & \multirow{2}{*}{$\begin{array}{l}\text { Photosensitivity, localised } \\
\text { skin reaction: erythema, } \\
\text { papular eruptions }\end{array}$} & Norflex Gel (30 g) & R 46.35 \\
\hline & & & & Norflex Gel (75 g) & R 115.87 \\
\hline \multirow[t]{6}{*}{ Diclofenac } & \multirow[t]{6}{*}{ Gel } & \multirow{6}{*}{$\begin{array}{l}\text { Apply } 2-4 \mathrm{~g} \text { to affected area } 3-4 \\
\text { hourly (dose to not exceed } 32 \mathrm{~g} \text { ) }\end{array}$} & \multirow{3}{*}{$\begin{array}{l}\text { Local skin irritation, } \\
\text { photosensitivity, eczema, } \\
\text { rash, hypersensitivity, }\end{array}$} & Voltaren Emulgel (20 g) & R 34.52 \\
\hline & & & & Voltaren Emulgel (50 g) & R 86.38 \\
\hline & & & & Voltaren Emulgel (100 g) & R 174.94 \\
\hline & & & \multirow{2}{*}{$\begin{array}{l}\text { Photosensitivity, Steven } \\
\text { Johnsons Syndrome, toxic } \\
\text { epidermal necrosis }\end{array}$} & Panamor Gel (30 g) & R 38.61 \\
\hline & & & & Panamor Gel $(60 \mathrm{~g})$ & R 77.22 \\
\hline & & & Itch, erythema, rash & Athruderm $(50 \mathrm{~g})$ & R 50.73 \\
\hline Flurbiprofen & Patch & Apply one patch 12 hourly & Localised reactions & Trans-Act (10 patches) & R 199.25 \\
\hline Indomethacin & Spray & $\begin{array}{l}\text { Spray } 2 \mathrm{ml} \text { ( } \pm 25 \text { sprays) on affected } \\
\text { area 3-5 times daily }\end{array}$ & Skin irritation & Elmetacin $(50 \mathrm{ml})$ & R 99.58 \\
\hline Ketoprofen & Gel & $\begin{array}{l}2-4 \mathrm{~g} 6-12 \text { hourly (dose to not } \\
\text { exceed } 15 \mathrm{~g} \text { ) }\end{array}$ & Photosensitisation & Fastum (50 g) & R 63.89 \\
\hline \multirow[t]{2}{*}{ Piroxicam } & \multirow[t]{2}{*}{ Gel } & \multirow[t]{2}{*}{ Apply $3 \mathrm{~cm} \mathrm{3-4} \mathrm{times} \mathrm{daily}$} & \multirow{2}{*}{$\begin{array}{l}\text { Toxic epidermal necrolysis, } \\
\text { pemphigus vulgaris, } \\
\text { phototoxic reactions }\end{array}$} & Rheugesic (40 g) & R 43.90 \\
\hline & & & & Rheugesic (100 g) & R 109.76 \\
\hline
\end{tabular}




\section{Adjuvant Therapy}

Adjunct therapy is pharmacological therapy. Adjunct therapy is not only used to manage the side effects caused by pain medication, but can also be added on to assist patients who still have persistent pain, inflammation ${ }^{29}$ and other conditions like anxiety or depression. ${ }^{30,31}$

\section{Narcotics}

There are many narcotic products available on the market to help alleviate pain in sports injuries. However, the selection of a narcotic is based on personal preference. Fentanyl and morphine provideequalanalgesic effects. As a healthcare providerone could prescribe fentanyl when the use of morphine is contraindicated. Pethidine is not recommended as it is not a good analgesic and when used long term its metabolite, nor-pethidine, may cause seizures. Each narcotic has a different dosage at which it provides analgesia, therefore, dosing should be based on pain severity. Narcotics are generally used as short term treatment. In cases where they are being used long term, side effects of the narcotics should be taken into consideration. . $^{32,33}$

Morphine is the golden standard of strong narcotic treatment. Morphine is available as an immediate-release, prolonged release and an oral solution. Immediate-release formulations are used to individualise patient dosages. Prolonged-release formulations help improve patient compliance to therapy. Oral solutions can be given, if the patient is unable to swallow tablets. ${ }^{34}$

Narcotic analgesics do not exhibit a ceiling effect. It is therefore important to use pain management scales in order to ensure that adequate analgesia is being provided with the least amount of side effects present. Medicines used to treat narcotic overdoses like naloxone should be kept within a healthcare facility in case adverse effects or complications are experienced. ${ }^{30}$

When a patient no longer requires the use of narcotics, it should be slowly tapered down. Whilst tapering down the narcotic dosage, it is important to monitor the patient's vital signs and ensure that he/she is pain free. The immediate removal of narcotics can lead to withdrawal symptoms..$^{35}$

\section{Combination Narcotic Formulations}

Combination therapy includes the use of one or more narcotic agents and a non-narcotic agent. Combination therapy should be considered when pain management is not under control. The advantage of using combination therapy is that doses of the medicine are usually lower than when it is administered by itself. Combination therapy has proven to be more beneficial than a one agent approach in post-surgical patients. Prescribers and dispenses should always be alert for previous substance abusers or patients who suffer from seizures or are on any antidepressants (SSRIs, MOA inhibitors). ${ }^{36,37}$

In 1986, the World Health Organization (WHO) realised the need for addressing pain management in patients. A simple algorithm was developed for the introduction and titration of pain medication in patients. This later became known as the 'WHO analgesic ladder'.38

The ladder consists of 5 recommendations for the correct use of pain medicine ${ }^{33}$ :

- The oral route should be used whenever possible

- The dosing interval should be individualised depending on how much pain the patient is in and agent's duration off efficacy.

- Medication should only be prescribed once the patient has received a clinical examination. This way, the way the patient feels is taken into consideration.

- Individualised dosages should be used. Every patient will perceive pain differently, thus dosages should be adjusted according to the level of pain the patient is experiencing.

- Compliance to pain medicine is crucial for pain management. Thus, patients or their caregivers/family members should understand the type of medicine they are on and how to administer it.

\section{Muscle Relaxants}

Muscle relaxants are reserved for when conventional analgesia does not supress pain adequately. Muscle relaxants act by relieving muscle spasm and thereby relieving pain and discomfort. $^{38}$

Table 8: Formulations, receptors and doses of opioids

\begin{tabular}{|c|c|c|c|}
\hline Types & Dosage forms & Receptor activity & Doses \\
\hline Morphine & $\begin{array}{l}\text { Tablets } \\
\text { Intravascular injection } \\
\text { Subdermal patch } \\
\text { Oral syrup }\end{array}$ & mu-( $\mu$ ) and kappa-(k) opioid receptors & $\begin{array}{l}\text { Oral: } 5-30 \mathrm{mg} \mathrm{3-4hrly} \\
\text { IM 5-10mg 3-4 hourly } \\
\text { IV } 1-2.5 \mathrm{mg} 5-10 \text { mnts up to } 15 \mathrm{mg}\end{array}$ \\
\hline Hydromorphine & Tablets & mu-( $\mu)$ and kappa-(k) opioid receptors & 4-8mg every daily \\
\hline Codeine & $\begin{array}{l}\text { Tablets } \\
\text { Oral syrup }\end{array}$ & $\begin{array}{l}\text { Partial affinity for k-receptors and } \mu \text { receptors, } \\
\text { strong affinity for delta }(\delta) \text { receptor }\end{array}$ & PO 30-60 mg 4-6 hourly \\
\hline Hydrocodone & Tablets & mu- $(\mu)$ and kappa-(k) opioid receptors & 5-10 mg 4-6 hourly \\
\hline Fentanyl & $\begin{array}{l}\text { Intravascular solution } \\
\text { Transdermal Patch }\end{array}$ & mu-(u) receptor & $\begin{array}{l}\text { IV } 25-50 \mathrm{mcg} / \mathrm{hr} \\
\text { IM } 50-100 \mathrm{mcg} / \mathrm{hr} \\
\text { Transdermal } 25 \mathrm{mcg} / \mathrm{h} \text { every } 72 \text { hours }\end{array}$ \\
\hline Methadone & $\begin{array}{l}\text { Oral linctus } \\
\text { intramuscular }\end{array}$ & Delta $(\delta)$ receptor & $\begin{array}{l}\text { PO 10-25 mg 3-4hrly } \\
\text { IM 10-25 mg 8-12 hourly }\end{array}$ \\
\hline
\end{tabular}




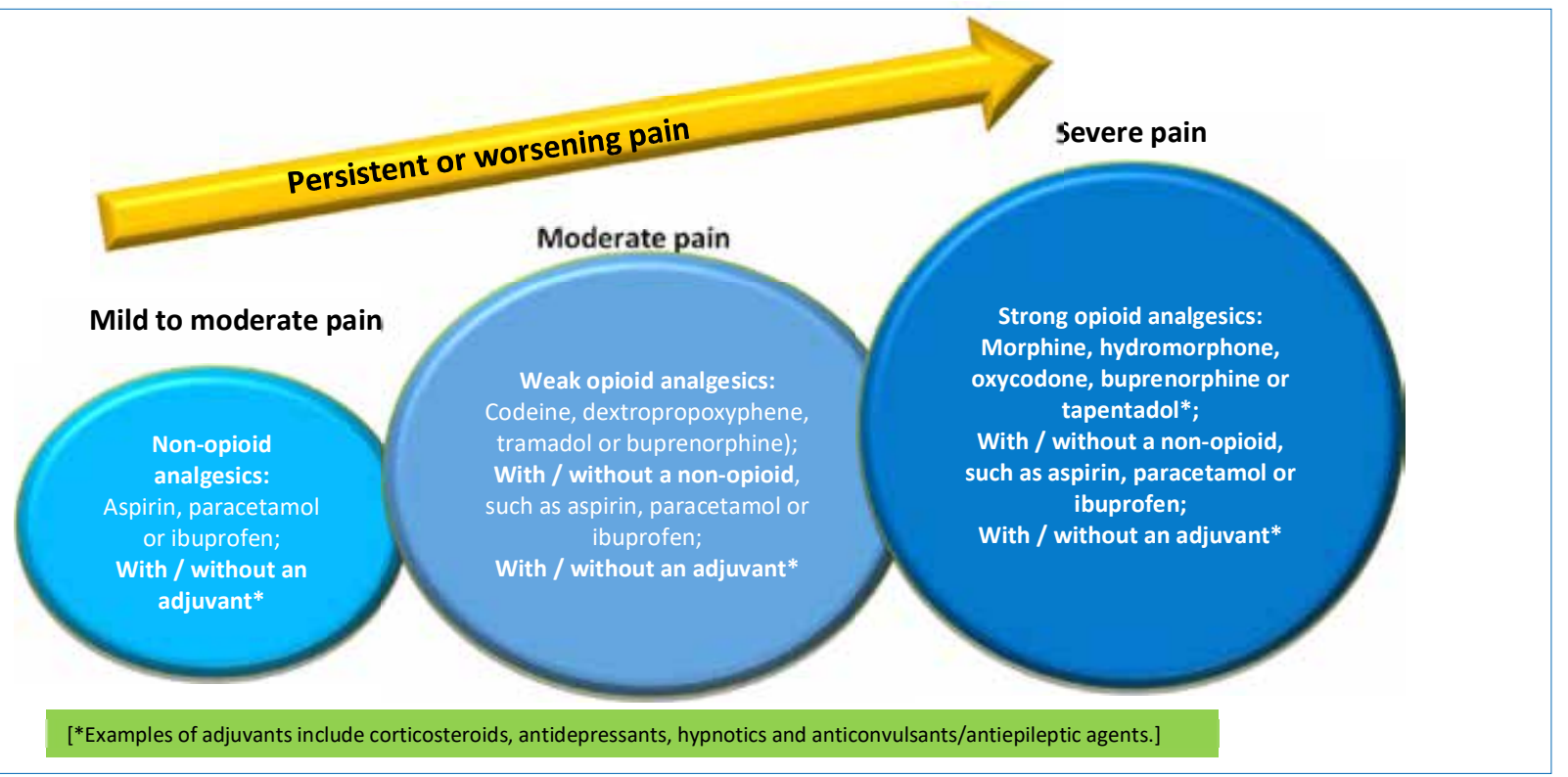

Figure 8: The World Health Organization's three-step analgesic guideline ${ }^{30}$

Muscle relaxants can be classified in two categories depending on their mechanism of action ${ }^{38}$ :

- Antispasmodics - act by relieving muscle spasms through alteration in central nervous system conduction.

- Antispastics - act by relieving hypertonicity and muscle spasms by either acting directly on the muscle or on the spinal cord.

\section{Conclusion}

Sport injuries, either caused by over exertion or trauma, lead to discomfort and may affect day-to-day activities. There are many treatment modalities available, however choosing a treatment approach should be dependent on a physical exam, the type of sports injury or muscle injury and the patient's compliance to the treatment regimen. Combination therapy should be a golden standard of therapy as most of the medication is synergistic and lower dose of each medicine will be needed to achieve pain relief. Non-pharmacological measures should also be emphasised when speaking to the patient because they are cost-effective and can be used multiple times a day to provide relief from pain and discomfort. Topical formulations of NSAIDs have proven to be highly efficacious in the management of sports injuries.

\section{References}

1. Selwood L. Topical treatment for sports injuries. S Afr Pharm J. 2015;82(7):18-21.

2. Hachigian Gould A. Sports Injuries: Types, Treatments, and Prevention. [Online] OnHealth. 2017 [accessed 4 Sep 2017]. Available at: http://www.onhealth.com/ content/1/sports_injuries

3. Johnson MI. Transcutaneous electrical nerve stimulation (TENS). eLS. 2012.

4. Snyman JR. (ed.). Musculo-Skeletal Agents: Topical Agents. Monthly Index Medical Specialities (MIMS). Cape Town: CTP Printers. 2018;58(7):89.

5. Lundborg $M$, Wennberg $C L$, Narangifard A, Lindahl E, Norléne L. Predicting drug permeability through skin using molecular dynamics simulation. J Control Release. 2018 [accessed 30 Aug 2017];283:269-279. Available at: https://www. sciencedirect.com/science/article/pii/S016836591830292X

6. Casale R, Symeonidou Z, Bartolo M. Curr Pain Headache Rep. 2017 [accessed 31 Aug 2017];21:15. Available at: https://doi.org/10.1007/s11916-017-0615-y
7. Liedtke R. Method and composition for topical therapy of back pain and muscle tension. United States Patent. 1998 [accessed 30 Aug 2017]. Available at: https:// patents.google.com/patent/US5776952A/en\#patentCitations

8. Hao J, Ghosh P, Li S, Newman B, Kasting G, Raney S. Heat effects on drug delivery across human skin. Expert Opinion on Drug Delivery. 2016 [accessed 30 Aug 2017];13(5):755-68. Available at: https://www.tandfonline.com/action/showCitF ormats?doi=10.1517\%2F17425247.2016.1136286

9. Scheupleins R. Permeability of the skin: a review of major concepts and some new developments. J Investig Dermatol. 1976 [accessed 30 Aug. 2017];67:672-6. Available at: https://core.ac.uk/download/pdf/82288223.pdf

10. Hagen $M$, Baker M. Skin penetration and tissue permeation after topical administration of diclofenac. Curr Med Res Opin. 2017 [accessed 30 Aug 2017];33(9):1623-34. Available at: https://www.tandfonline.com/doi/abs/10.108 0/03007995.2017.1352497

11. Lefevre N, Bohu Y, Herman S, Klouche S, Servien E. Major Causes of Sports Injuries. 2017.

12. Niams.nih.gov. Handout on Health: Sports Injuries. [Online] 2017 [accessed 28 Aug 2017]. Available at: https://www.niams.nih.gov/health_info/ sports_injuries/\#ra_17

13. Peterson L, Per Renström AFH. Sports Injuries: Prevention, Treatment and Rehabilitation. 4th Ed, Sweden: CRC Press; 2016.

14. Summitmedicalgroup.com. Overuse Injuries | Summit Medical Group. [Online] 2017 [accessed 28 Aug 2017]. Available at: http://www.summitmedicalgroup. com/news/fitness/Overuse-Injuries/.

15. ACSM. 2017 [accessed 29 Aug 2017]. Online. Available at: https://www.acsm.org/ docs/brochures/sprains-strains-and-tears.pdf

16. Hoffman M. The Seven Most Common Sports Injuries. [Online] WebMD. 2017 [accessed 30 Aug 2017]. Available at: http://www.webmd.com/men/features/ seven-most-common-sports-injuries\#2

17. Elastoplast.com.au. Sports Injury Management | Elastoplast. [Online] 2017 [accessed 30 Aug 2017]. Available at: https://www.elastoplast.com.au/ strapping-and-injuries/injury-management-and-prevention/injury-management

18. Harvard Health. Treating sports injuries - Harvard Health. [Online] Harvard Health. 2017 [accessed 30 Aug 2017]. Available at: https://www.health.harvard. edu/newsletter_article/treating-sports-injuries

19. Vance C, Rakel B, Dailey D, Sluka K. Skin impedance is not a factor in transcutaneous electrical nerve stimulation effectiveness. J Pain Res. 2015;571.

20. Wilkonson J, Falerio R. Acupuncture in pain management. BJA Educ. 2007;7(4):135-8.

21. Draper D, Hawkes A, Johnson A, Diede M, Rigby J. Muscle Heating With Megapulse II Shortwave Diathermy and ReBound Diathermy. J Athl Train. 2013;48(4):477-82.

For a full set of references please see http://www.safpj.co.za 
22. Verghese ST, Hannallah RS. Acute Pain Management in Children. J Pain Res. 2010;3:105-23.

23. Batten G. The Role of Medications in the Treatment of Sports-Related Injuries Tri-Valley Orthopedic Specialists. [Online] Tri-Valley Orthopedic Specialists. 2017 [accessed 30 Aug 2017]. Available at: http://www.trivalleyorthopedics.com/ the-role-of-medications-in-the-treatment-of-sports-related-injuries/.

24. The International Consensus Group for Neonatal Pain. New guidelines for management of neonatal pain. Arch Pediatr Adolesc Med. 2001;155(2):173-80.

25. Ottani A, Leone S, Maurizio S, Ferrari A, Bertolini A. The analgesic activity of paracetamol is prevented by the blockade of cannabinoid CB1 receptors. Eur J Pharmacol. 2006;531(1):280-1.

26. Cohen LL, Lemanek K, Blount RL, Dahlquist LM, Lim CS, Palermo TM, et al. Evidence-based Assessment of Pediatric Pain. J Pediatr Psychol. 2007;10:1093.

27. Zarghi A, Arfaei S. Selective COX-2 Inhibitors: A Review if Their Structure Activity Relationships. IJPR. 2011 [accessed 13 Jan 2017];10(4). Available at: https://www. ncbi.nlm.nih.gov/pmc/articles/PMC3813081/.

28. Derry S, Moore RA, Gaskell H, McIntyre M, Wiffen PJ. Topical NSAIDs for acute musculoskeletal pain in adults. Cochrane Database Syst Rev. 2015;6:CD007402.

29. Nhs.uk. Sports injuries - Treatment - NHS Choices. [Online] 2017 [accessed 30 Aug 2017]. Available at: http://www.nhs.uk/conditions/Sports-injuries/Pages/ Treatment.aspx

30. WHO guidelines on the pharmacological treatment of persisting pain in children with medical illnesses. [Homepage on internet]. 2012 [accessed 12 Jan 2017]. Available at: http://www.who.int/medicines/areas/quality_safety/ guide_perspainchild/en/
31. Vargas-Schaffer G. Is the WHO analgesic ladder still valid?: Twenty-four years of experience. Can Fam Physician. 2010;56(6):514-7.

32. Bouwmeester J, Van Dijk M, Tibboel D. Human neonates and pain. In: Hendriksen CFM, Morton DB, eds. Humane endpoints in animal experiments for biomedical research. London: Royal society of medicine press; 1999.

33. Palermo TM, Valrie CR, Karlson CW. Family and Parent Influences on Pediatric Chronic Pain. American Psychological Association. Department of Anesthesiology and Pain Medicine, University of Washington and Center for Child Health, Behaviour and Development, Seattle Children's Research Institute, Seattle, Washington;2014;69( 2):142-52.

34. Park HJ, Dong EM. Pharmacologic Management Of Chronic Pain. Korean J Pain. 2010;23(2):99-108.

35. Blondell RD, Azadfard M, Wisnieeski A. Pharmacologic therapy for acute pain. Am Fam Physicians. 2013;87(11):765-72.

36. Ballantyne J, Kalso E, Stannard C. WHO analgesic ladder: a good concept gone astray. BMJ. (2016);i20.

37. Baumann TJ, Herndon CM, Strickland JM. Pain Management. In: DiPiro JT, Talbert RL, Yee GC, Matzke GR, Wells BG, Posey L. eds. Pharmacotherapy: A Pathophysiologic Approach, 9e. New York, NY: McGraw-Hill; 2014 [accessed 13 Jan 2017]. Available at: http://accesspharmacy.mhmedical.com/content.aspx?bo okid=689\&Sectionid $=45310494$.

38. Witenko C, Mooman-Li R, Motycka C, Duane K, Hincapie-Castillo J, Leonard P, Valaer $C$. Considerations for the appropriate use of skeletal muscle relaxants for the management of acute low back pain. J Clin Pharm Ther. 2014;39(6):427-35. 